\title{
MADM AND FUTURES STUDIES; A NECESSITY
}

\author{
Sarfaraz Hashemkhani Zolfani ${ }^{1}$, Reza Maknoon $^{2}$, Edmundas Kazimieras Zavadskas ${ }^{3}$ \\ 1, 2 Department of Management, Science and Technology, Technology Foresight Group, \\ Amirkabir University of Technology (Tehran Polytechnic), \\ P.O. Box 1585-4413, Hafez Street, Farabi Building, Tehran, Iran \\ ${ }^{3}$ Institute of Internet and Intelligent Technologies, Vilnius Gediminas Technical University, \\ Sauletekio al. 11, LT-10223 Vilnius, Lithuania \\ E-mails: ${ }^{1}$ sa.hashemkhani@gmail.com (correspondingauthor); ${ }^{2}$ rmaknoon@yahoo.com; \\ ${ }^{3}$ edmundas.zavadskas@vgtu.lt
}

\begin{abstract}
Multiple Attribute Decision Making (MADM) has been developing in different methods, perspectives and frameworks since introducing step. Futures Studies as a specialized framework and methodology has introduced newer and has been always in developing phase too. MADM as a part of Multiple Criteria Decision Making is known as multi-disciplinary approach, framework and methodology. Nowadays, Futures Studies is also known as multi-disciplinary approach too. Basically, MADM is structured for a stable environment while most decisions need to be made, dynamically. Time is so much important especially in the new century in comparison with the past. Decisions making about future are usually so complicated and MADM can be helpful in that process. Importance of making future based decisions is undeniable in trying to answer to decision needs. This research will present a comprehensive review on the literature of MADM and new orientations in considering future in MADM models and necessity of them will be checked also carefully. Eventually, importance of seeing both MADM and Futures Studies together as a unit model will be discussed in this study.
\end{abstract}

Keywords: Multiple Attribute Decision Making (MADM), Multiple Criteria Decision Making (MCDM), Futures Studies, MADM based Scenarios, Dynamic MADM (DMADM), Prospective MADM (PMADM).

JEL Classification: C02; C44; C61.

\section{Introduction}

Multiple Attribute Decision Making (MADM) and Multi-objective Decision Making (MODM) are sub-categories of Multi-Criteria Decision Making (MCDM) (Liou, Tzeng 2012; Zavadskas et al. 2014). MADM is a widespread methodology in decision making about different topics and fields. Nowadays, decision making with MADM methods is so common in so many vital issues like: economics, society, management science and etc (Chai et al. 2013; Wang et al. 2013; Aguezzoul 2014; Mardani et al. 2015; Hashemkhani Zolfani et al. 2016a). Today, MADM can be considered as a multi-disciplinary methodology in process of decision making and problem solving (Ishizaka, Labib 2011; Behzadian et al. 2012; Aguezzoul 2014; Mardani et al. 2015).

From introducing SAW (McCrimon 1968) till now so many methods has been developed in MADM field as sub-field of MCDM such as:

AHP (Saaty 1980), TOPSIS (Hwang, Yoon 1981), ELECTRE (Roy 1968), PROMETHEE (Brans et al. 1984), MACBETH (Bana e Costa,
Vansnick 1994), COPRAS (Zavadskas, Kaklauskas 1996), VIKOR (Opricovic 1998), MOORA (Brauers, Zavadskas 2006), ARAS (Zavadskas, Turskis 2010), SWARA (Keršulienè et al. 2010), WASPAS (Zavadskas et al. 2012), FARE (Ginevicius 2011), MULTIMOORA (Brauers, Zavadskas 2010), BWM (Rezaei 2015) and EDAS (Keshavarz Ghorabaee et al. 2015).

Decision making about dynamic situations, challenges and policies has been a common act since previous century in all around the world. During the previous decade dynamic perspective has added in different ways into the MADM structure and methodology (Xu 2008; Lou et al. 2010; Campanella, Ribeiro 2011; Trutnevyte et al. 2012; Zhang 2012; Durbach, Stewart 2012a; Hashemkhani Zolfani et al. 2013; Tadic et al. 2014; Gonzalez-Prida et al. 2014; Jassbi et al. 2014).

Usually dynamic situation for decision making is related to the future topics. It means dynamic situation is critical and vital for actions and should be linked to the future decision and policy making. 
Recently some researchers interested in considering future in their decision models in different ways but primarily. Definition of dynamic MADM model has defined in recent studies and different dimensions.

This research is going to criticize MADM history and structure from the base up to now. The main aim is an investigation on MADM framework and methodology to clarify and identify relationship between MADM and futures studies. Decision making is on more dynamic road and MADM can't be considered as an exception. All new trends in MADM will be checked in this study.

\section{Latest contributions related to the MADM and Future Studies}

This part is designed in two sections includes: 1. All achievements in classic MADM structure, 2. All contributions on MADM framework and future studies' methodologies.

\subsection{All achievements in classic MADM structure}

Dynamic decision making based on MADM structure has been developing since from 1980s. Ozernoy (1988) gave some information about application of MCDM methods in R\&D Project selection in USSR, 1971-1986. That research has shown future thinking about developing phase since about half of a century and based on MCDM framework.

Leong (1998) worked specifically on responding to the dynamic needs in MADM structure. Time and uncertainty have considered as different positions and situations in the model. Different answers will be ready for each time and situation.

Salo et al. (2003) presented new perspective in technology foresight about R\&D projects' evaluation. MADM methods applied to this process and MADM has considered as a core for projects' evaluation. The study just considered a probable future as the base and nothing new as the methodology was in that.

Interval data considered as the weight of criteria, dynamically. Xu (2008) considered different relative importance for criteria using interval data in different time periods. Different answers for each decision making problem will be generated based on this perspective which can't be a comprehensive structure, eventually.

Lou et al. (2010) applied time series analysis and historic data due to need of considering
MADM, dynamically. The research doesn't have any direct relation to the future studies but prediction could be considered as a good start in futures studies' area.

A primary model for dynamic MADM presented based on historic data from past experiences and with current data. Based on Campanella and Ribeiro (2011) the model had something new but future didn't see in that as a dynamic decision making model.

Zhang (2012) presented applicable and useful idea about dynamic MADM model which the model could consider different periods of time. Three different time periods considered and this perspective can be considered as a primary model to future needs of decision making.

Considering foresight perspective was another contribution into MADM model. From the base a research decision making problem can be structured based on foresight perspective. Hashemkhani Zolfani et al. (2013) consider this perspective in a locating topic about shopping mall site selection.

Wang et al. (2013) considered grey numbers in evaluating MADM model in a time period. Considering vagueness based on grey interval numbers was contribution of the study.

Gonzalez-Prida et al. (2014) presented a new dynamic model for AHP (DAHP). Similarly to Campanella and Ribeiro (2011) past data considered with current data and also considered that for AHP method. Although the research didn't consider future but had something new as a contribution to the literature.

Ondrus et al. (2015) developed based on Salo et al. (2003) study. This research applied computer calculations and visualization to the previous structure in project selection as a part of technology foresight process. Another innovation of this research was this ability for each expert to develop his/her criteria for the model.

The latest model for DMADM has presented by Jassbi et al. (2014) in generating a new model for MADM. Past, current and prediction as future information have considered in that new DMADM model and as the main contribution. Although foresight and futures studies weren't in the model directly, future considered somehow in the structure.

\subsection{All contributions on MADM framework and future studies' methodologies}

Supriyasilp et al. (2009) used MCDM structure in evaluating two different scenarios for hydropower development priorities. Each scenario was consid- 
ered separately in the evaluation process. Browne et al. (2010) applied MCDM framework for evaluating scenarios. That process considered to identify the best scenario.

Durbach and Stewart (2012b) analyzed the scenarios with MADM framework with fuzzy numbers. That research tried to consider uncertainties in the decision making models. Petit and Fraser (2012) worked on energy section. Different scenarios were evaluated based on AHP method in that study.

Ribeiro et al. (2013) evaluated future scenarios based on MCDA model. They just analyzed the scenarios based on a set of criteria. Optimization also was used in the study in generating scenarios. Marzouk et al. (2013) considered different scenarios as the alternatives for evaluating proposed projects. The final evaluation was planned based on MADM framework.

Ram and Montibeller (2013) worked on a new concept entitled Scenario-based MCDA methods for robust choice. Each scenario analyzed based on MCDM framework. Stewart et al. 2013 introduced a new concept in evaluating scenarios based on MCDM methods and called meta-criteria which work as a combination between scenarios and primary criteria.

Chung and Kim (2014) used fuzzy TOPSIS for evaluating future scenarios about climate change. Also results of TOPSIS and fuzzy TOPSIS compared to each other.

Sawicka and Zack (2014) applied ELECTRE III as a stochastic model in evaluating scenarios in a new approach. All scenarios ranked and assessed based on the stochastic MADM method. Streimikienè et al. (2016) assessed different scenarios about generation of technologies in electricity section with a hybrid MADM model, AHP-ARAS, as the methodology of the research. All five scenarios were evaluated based on the hybrid MADM method.

\section{Comments on MADM and future studies}

Due to latest research articles about dynamic MADM (DMADM) it can be concluded that decision making about future issues is still vague and complicated. Classic structure of MADM models couldn't create a good answer to the needs and research questions about future. Considering decision environment as a stable situation for the future is completely a wrong perspective. Recently, two new perspectives have added to the MADM literature.

Hashemkhani Zolfani et al. (2016a) presented a new combination between two multi-disciplinary research fields, Futures Studies and MADM. This research presented a new perspective in decision making with MADM about the future. In opposite side of scenarios based MCDM, this research has designed when different future scenarios can shape our decision models in practice. For each scenario one MADM model created in that study and final decision about the future made based most affective criterion and applicable alternative. This study is shown that hybrid models based future studies' methodologies and MADM structures can be helpful as a new inter-disciplinary framework.

Hashemkhani Zolfani et al. (2016b) presented a new perspective and sub-field in MADM framework. Dynamic MADM (DMADM) has been developing during the last decade woth different approaches and perspectives. This study is the latest contribution about considering future in multiple attribute decision models. Prospective MADM (PMADM) is focused on the decision making based on future aspects of issues and their dimensions. Due to this research MADM can be developed for future perspectives. For the first step, limiters have introduced as a new part which can be added to classis structure of MADM structure. One of classic MADM methods, WASPAS, has developed as PWASPAS based on new perspective, adding limiters, to show this new contribution in practice. This model of PWASPAS also can be developed in the future research and in the new probable contributions of PMADM model.

PMADM model can be developed in two key phases: 1. developing classic dimensions such as relative importance of criteria and weighting those. 2. Adding other new sections as new parts of MADM model such as what introduced in first PMADM model, limiters, in practice. It can be predicted these approaches will be developed in the near future in helping decision making about future and with multiple attribute decision structures.

\section{Future of MADM and future studies}

As mentioned above, two parts can be considered as intersection of MADM and Futures Studies in general point of view. These two parts include: 1 . MADM and futures studies methods, 2. Prospective MADM as a new specialized sub-field.

\subsection{MADM and future studies methods}

MADM has been applying in different ways with scenarios such as: Scenarios based MADM and MADM based scenarios. But this structure is ac- 
ceptable and applicable for other Futures Studies methods and methodologies. For example, MADM can be used in Backcasting in terms of evaluating different options and priorities and also in different time periods. Other methodologies also are useful for research about the future. For other instance, game theory is helpful about decision making process for the future. Hashemkhani Zolfani and Seyed Agha Banihashemi (2014), and Hashemkhani Zolfani et al. (2015) applied MADM methods in decision making process with game theory in practice. MADM can be applied for supporting game theory in future decision making and different ways and frameworks in it. These kinds of intersections can be developed more in the near future. With this idea, results can be considered more reliable from both MADM and Futures Studies perspectives.

\subsection{Prospective MADM as a new specialized sub-field}

Prospective MADM (Hashemkhani Zolfani et al. 2016b) has introduced lately with a completely new idea about applying future thinking in the decision making process. It can be considered just what PMADM is and how does it work presented in a research study. A new element added to the classic form of MADM structure and this element shows that MADM framework can be developed more in dynamic forms.

Decision making for the future is so complicated and it is hard to do it just with previous experiences in decision making frameworks. Dynamic MADM couldn't answer to all these needs up to now and now it can be seen PMADM has something new with appropriate ability to answer to the decision making process needs.

PMADM haven't limited in methodology and other elements can be developed in different perspectives. Classic elements of MADM also can be advanced with different frameworks and structures. With developing futures studies as a more specialized multi-disciplinary and inter-disciplinary field, developing methodologies for this new area it seems inevitable. There are so many postgraduate fields for futures studies in USA, Finland, Taiwan, Australia, Iran and etc.

\section{Conclusion}

Futures Studies and foresight have been developing in the new century more than all the history. Methods have been emerging in Futures Studies since about 60 years ago. Nowadays, methods are still in developing phase and can be considered as methodologies. So many methodologies and methods have recognized for Futures Studies and foresight such as: Scenario Planning, Casual Layered Analysis (CLA), Backcasting and etc. As a field, Futures Studies still has a scientific capacity to be developed more and more. Also other methods and methodologies are in developing steps to be equipped by future perspective and structures.

In general, Multiple Criteria Decision Making (MCDM) is a useful methodology in Futures Studies and actions as a foresight system. Due to needs this framework has been developing in the new century and because of that so many research articles have focused on this topic. MADM as a major part of MCDM is more related to future decisions in practice and in comparison with MODM. Dynamic MADM (DMADM) has been developing in latest years but couldn't still answer to future needs in decision making process in practice and action.

The latest contributions about applying future trends in decision making process presented as MADM based scenarios and Prospective MADM (PMADM). Based on these two new contributions, intersections of MADM and Futures Studies have separated in two sections: MADM and futures studies methods, 2. Prospective MADM as a new specialized sub-field. From now to the next decade Futures Studies and MADM will be in cooperating through these two categories. PMADM, especially, is in the first step and can be continued in different methods, perspectives and frameworks.

As a conclusion, relation between MADM and Futures Studies is inevitable. MADM couldn't save its position in the scientific societies and scholars without this new trend. Nowadays, decision making become more and more complicated. Decision making methodologies and methods should be directed to this new trend. It can be predicted MADM and PMADM can be linked as a methodology in Futures Studies field in the near future.

\section{References}

Aguezzoul, A. 2014. Third-party logistics selection problem: A literature review on criteria and methods, Omega 49: 69-87.

http://dx.doi.org/10.1016/j.omega.2014.05.009

Bana e Costa, C. A.; Vansnick, J. C. 1994. MACBETH: an interactive path towards the construction of cardinal value functions, International Transactions in Operational Research 1(4): 489-500. http://dx.doi.org/10.1016/0969-6016(94)90010-8

Behzadian, M.; Khanmohammadi Otaghsara, S.; Yazdani, M.; Ignatius, J. 2012. A state-of the-art survey 
of TOPSIS applications, Expert Systems with Applications 39(17): 13051-13069.

http://dx.doi.org/10.1016/j.eswa.2012.05.056

Brans, J. P.; Mareschal, B.; Vincke, P. 1984. PROMETHEE: a new family of outranking methods in multicriteria analysis, in J. P. Brans (Ed.). Operational Research '84 IFORS 84, 6-10 August 1984, Washington, D.C., USA. North Holland, 477-490.

Brauers, W. K. M.; Zavadskas, E. K. 2006. The MOORA method and its application to privatization in a transition economy, Control and Cybernetics 35(2): 443-468.

Brauers, W. K. M.; Zavadskas, E. K. 2010. Project management by MULTIMOORA as an instrument for transition economies, Technological and Economic Development of Economy 16(1): 5-24. http://dx.doi.org/10.3846/tede.2010.01

Browne, D.; O’Regan, B.; Moles, R. 2010. Use of multi-criteria decision analysis to explore alternative domestic energy and electricity policy scenarios in an Irish city-region, Energy 35: 518-528. http://dx.doi.org/10.1016/j.energy.2009.10.020

Campanella, G.; Ribeiro, R. A. 2011. A framework for dynamic multiple-criteria decision making, Decision Support Systems 52: 52-60. http://dx.doi.org/10.1016/j.dss.2011.05.003

Chai, J.; Liu, J. N. K.; Ngai, E. W. T. 2013. Application of decision-making techniques in supplier selection: a systematic review of literature, Expert Systems with Applications 40(10): 3872-3885. http://dx.doi.org/10.1016/j.eswa.2012.12.040

Chung, E. S.; Kim, Y. 2014. Development of fuzzy multi-criteria approach to prioritize locations of treated wastewater use considering climate change scenarios, Journal of Environmental Management 146: 505-516.

http://dx.doi.org/10.1016/j.jenvman.2014.08.013

Durbach, I. N.; Stewart, T. J. 2012a. Modeling uncertainty in multi-criteria decision analysis, European Journal of Operational Research 223: 1-14. http://dx.doi.org/10.1016/j.ejor.2012.04.038

Durbach, I.; Stewart, T. 2012b. A comparison of simplified value function approaches for treating uncertainty in multi-criteria decision analysis, Omega 40: 456-464.

http://dx.doi.org/10.1016/j.omega.2011.08.004

Ginevicius, R. 2011. A new determining method for the criteria weights in multi-criteria evaluation, International Journal of Information Technology \& Decision Making 10(6): 1067-1095.

http://dx.doi.org/10.1142/S0219622011004713

Gonzalez-Prida, V.; Viveros, P.; Barbera, L.; Crespo Marquez, A. 2014. Dynamic analytic hierarchy process: AHP method adapted to a changing environment, Journal of Manufacturing Technology Management 24(4): 457-475.
Hashemkhani Zolfani, S.; Aghdaie, M. H.; Derakhti, A.; Zavadskas, E. K.; Morshed Varzandeh, M. H. 2013. Decision making on business issues with foresight perspective; an application of new hybrid MCDM model in shopping mall locating, Expert Systems with Applications 40: 7111-7121.

http://dx.doi.org/10.1016/j.eswa.2013.06.040

Hashemkhani Zolfani, S.; Seyed Agha Banihashemi, S. 2014. Personnel selection based on a novel model of game theory and MCDM approach, in $8^{\text {th }}$ International Scientific Conference "Business and Management 2014”, 15-16 May 2014, Vilnius, Lithuania, 191-198.

Hashemkhani Zolfani, S.; Maknoon, R.; Zavadskas, E. K. 2015. Multiple Nash Equilibriums and evaluation of strategies. New application of MCDM methods, Journal of Business Economics and Management 16(2): 290-306.

http://dx.doi.org/10.3846/16111699.2014.967715

Hashemkhani Zolfani, S.; Maknoon, R.; Zavadskas, E. K. 2016a. Multiple Attribute Decision Making (MADM) based scenarios, International Journal of Strategic Property Management 20(1): 101-111.

http://dx.doi.org/10.3846/1648715X.2015.1132487

Hashemkhani Zolfani, S.; Maknoon, R.; Zavadskas, E. K. 2016b. An introduction to Prospective Multiple Attributes Decision Making (PMADM), Technological and Economic Development of Economy 22(2): 309-326.

http://dx.doi.org/10.3846/20294913.2016.1150363

Hwang, C. L.; Yoon, K. 1981. Multiple attribute decision making: a state of the art survey: Lecture Notes in Economics and Mathematical Systems, vol. 186. Berlin: Springer-Verlag. http://dx.doi.org/10.1007/978-3-642-48318-9

Ishizaka, A.; Labib, A. 2011. Review of the main developments in the analytic hierarchy process, Expert Systems with Applications 38(11): 14336-14345.

Jassbi, J. J.; Ribeiro, R. A.; Varela, L. R. 2014. Dynamic MCDM with future knowledge for supplier selection, Journal of Decision Systems 23(3): 232248.

http://dx.doi.org/10.1080/12460125.2014.886850

Keršulienè, V.; Zavadskas, E. K.; Turskis, Z. 2010. Selection of rational dispute resolution method by applying new step-wise weight assessment ratio analysis (SWARA), Journal of Business Economics and Management 11(2): 243-258.

http://dx.doi.org/10.3846/jbem.2010.12

Keshavarz Ghorabaee, M.; Zavadskas, E. K.; Olfat, L.; Turskis, Z. 2015. Multi-criteria inventory classification using a new method of evaluation based on distance from average solution (EDAS), Informatica 26(3): 435-451.

http://dx.doi.org/10.15388/Informatica.2015.57

Leong, T. Y. 1998. Multiple perspective dynamic decision making, Artificial Intelligence 105: 209-261.

http://dx.doi.org/10.1016/S0004-3702(98)00082-4 
Liou, J. J. H.; Tzeng, G. H. 2012. Comments on "MULTIPLE CRITERIA DECISION MAKING (MCDM) Methods in Economics: an overview", Technological and Economic Development of Economy 18(4): 672-695.

http://dx.doi.org/10.3846/20294913.2012.753489

Lou, C.; Kou, G.; Peng, Y.; Ge, X. 2010. DMCDM: a dynamic multi criteria decision making model for sovereign credit default risk evaluation, in $2^{\text {nd }} I n$ ternational Conference on Software Engineering and Data Mining (SEDM), 23-25 June 2010, Chengdu, China. IEEE, 489-494.

Mardani, A.; Jusoh, A.; Zavadskas, E. K. 2015. Fuzzy multiple criteria decision-making techniques and applications - two decades review from 1994 to 2014, Expert Systems with Applications 42(8): 4126-4148.

http://dx.doi.org/10.1016/j.eswa.2015.01.003

Marzouk, M.; Amer, O.; El-said, M. 2013. Feasibility study of industrial projects using Simos' procedure, Journal of Civil Engineering and Management 19(1): 59-68.

http://dx.doi.org/10.3846/13923730.2012.734855

McCrimon, K. R. 1968. Decision marking among multiple-attribute alternatives: a survey and consolidated approach. RAND Memorandum, RM-4823ARPA. The Rand Corporation, Santa Monica, Calif.

Ondrus, J.; Bui, T.; Pigneur, Y. 2015. A foresight support system using MCDM methods, Group Decision and Negotiation 24(2): 333-358. http://dx.doi.org/10.1007/s10726-014-9392-8

Opricovic, S. 1998. Multiple criteria optimization of civil engineering systems. Faculty of Civil Engineering, University of Belgrade (in Serbian).

Ozernoy, V. M. 1988. Multiple Criteria Decision Making in the USSR: a survey, Naval Research Logistics 35: 543-566. http://dx.doi.org/10.1002/ 1520-6750(198812)35:6<543::AIDNAV3220350604>3.0.CO;2-Q

Ram, C.; Montibeller, G. 2013. Exploring the impact of evaluating strategic options in a scenario-based multi-criteria framework, Technological Forecasting \& Social Change 80: 657-672.

http://dx.doi.org/10.1016/j.techfore.2012.09.019

Sawicka, H.; Zak, J. 2014. Ranking of distribution system's redesign scenarios using stochastic MCDM/A procedure, Procedia - Social and Behavioral Sciences 111: 186-196. http://dx.doi.org/10.1016/j.sbspro.2014.01.051

Petit, P. J.; Fraser, P. D. 2012. What is the best energy delivery systems for hand-held stope drilling and associated equipment in narrow-reef hard rock mines?, The Southern African Institute of Mining and Metallurgy, Platinum, 1037-1053.

Rezaei, J. 2015. Best-worst multi-criteria decisionmaking method, Omega 53: 49-57.

http://dx.doi.org/10.1016/j.omega.2014.11.009
Ribeiro, F.; Ferreira, P.; Araújo, M. 2013. Evaluating future scenarios for the power generation sector using a Multi-Criteria Decision Analysis (MCDA) tool: the Portuguese case, Energy 52: 126-136. http://dx.doi.org/10.1016/j.energy.2012.12.036

Roy, B. 1968. Classement et choix en presence de point de vue multiples: Le methode ELECTRE [Elimination and choice expressing reality], Revue Francaise d'Informatique et de Recherche Operationnelle (RIRO) 8: 57-75 (in French).

Saaty, T. L. 1980. The analytical hierarchy process. New York: McGraw-Hill.

Salo, A.; Gustafsson, T.; Ramanathan, R. 2003. Multicriteria methods for technology foresight, Journal of Forecasting 22: 235-255. http://dx.doi.org/10.1002/for.850

Stewart, T. J.; French, S.; Rios, J. 2013. Integrating multi-criteria decision analysis and scenario planning - review and extension, Omega 41: 679-688. http://dx.doi.org/10.1016/j.omega.2012.09.003

Štreimikienè, D.; Šliogerienè, J.; Turskis, Z. 2016. Multicriteria analysis of electricity generation technologies in Lithuania, Renewable Energy 85: 148156. http://dx.doi.org/10.1016/j.renene.2015.06.032

Supriyasilp, T.; Pongput, K.; Bonyasirikul, T. 2009. Hydropower development priority using MCDM method, Energy Policy 37(5): 1866-1875. http://dx.doi.org/10.1016/j.enpol.2009.01.023

Tadic, S. R.; Zecevic, S. M.; Krstic, M. D. 2014. Ranking of logistics system scenarios for central business district, Promet - Traffic \& Transportation 26(2): 159-167.

Trutnevyte, E.; Stauffacher, M.; Scholz, R. W. 2012. Linking stakeholder visions with resource allocation scenarios and multi-criteria assessment, European Journal of Operational Research 219: 762772 . http://dx.doi.org/10.1016/j.ejor.2012.01.009

Wang, J. Q.; Zhang, H. Y.; Ren, S. C. 2013. Grey stochastic multi-criteria decision-making approach based on expected probability degree, Scientia Iranica E20(3) 873-878.

$\mathrm{Xu}, \mathrm{Z}$. 2008. On multi-period multi-attribute decision making, Knowledge-Based Systems 21(2): 164171.

http://dx.doi.org/10.1016/j.knosys.2007.05.007

Zavadskas, E. K.; Kaklauskas, A. 1996. Determination of an efficient contractor by using the new method of multicriteria assessment, in D. A. Langford, A. Retik (Eds.). International Symposium for "The Organisation and Management of Construction". Shaping Theory and Practice 2: Managing the Construction Project and Managing Risk. CIB W 65; London, Weinheim, New York, Tokyo, Melbourne, Madras. - London: E and FN SPON, 94-104. 
Zavadskas, E. K.; Turskis, Z. 2010. A new additive ratio assessment (ARAS) method in multicriteria decision-making, Technological and Economic Development of Economy 16(2): 159-172. http://dx.doi.org/10.3846/tede.2010.10

Zavadskas, E. K.; Turskis, Z.; Antucheviciene, J.; Zakarevicius, A. 2012. Optimization of weighted aggregated sum product assessment, Electronics and Electrical Engineering (6): 3-6.
Zavadskas, E. K.; Turskis, Z.; Kildiene, S. 2014. State of art surveys of overviews on MCDM/MADM methods, Technological and Economic Development of Economy 20(1): 165-179.

http://dx.doi.org/10.3846/20294913.2014.892037

Zhang, Z. 2012. An approach to dynamic multi-attribute decision making for choosing green supplier, Journal of Convergence Information Technology 7(21): 261-269.

http://dx.doi.org/10.4156/jcit.vol7.issue21.33 